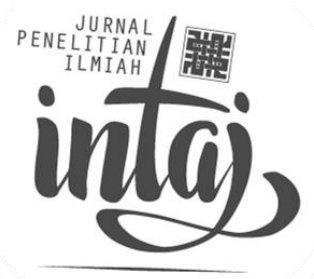

\title{
Pembelajaran Kitab Kuning di Pondok Pesantren Hidayatullah Ternate
}

\author{
Faizal Bachrong (faizal.bachrong@gmail.com) \\ Balai Penelitian dan Pengembangan Agama Makassar
}

(Received: Agustus 2018 / Revised: Februari 2019 / Accepted: Maret 2019)

\begin{abstract}
Pesantren is Islamic education institution that still be needed by the Ummah. The study of kitab kuning is an important element of it, and this generally tends to be stagnant, for various reasons. Therefore the study of the use of kitab kuning in pesantren is urgent. This research highlights the reality of kitab kuning study in boarding school, mainly Pondok Pesantren Hidayatullah Ternate. This is qualitative research in which the data collection techniques are interview, observation and study of documents and literature. The analysis of the data is qualitative description.

The result of this research shows that Pondok Pesantren Hidayatullah Ternate, which was established in 1994, includes a combination between Islamic boarding school system and formal education units in the form of schools and madrasas. Basically the santri are lodged. The boarding school students are junior and senior high school students, both male and female. The male and female campuses are separated by a distance of about $1 \mathrm{~km}$. They are all participated in tahfidz Alquran and ta'lim diniyyah. The books studied in this boarding school are limited to 5 books that outlined by the Central Executive, regarding Aqidah, Fikih, Tafsir, Sirah and Arabic. The study of these books uses lecture method and the santris only gather and heed without having the book.
\end{abstract}

Keywords: Islamic Boarding School, Hidayatullah Ternate, kitab kuning. 


\section{PENDAHULUAN}

Pesantren adalah lembaga pendidikan keagamaan tertua di Indonesia. Kepercayaan masyarakat Islam terhadap pesantren memperlihatkan konsistensinya meskipun lembaga pendidikan lainnya juga mengalami perkembangan. Hal ini terbukti dengan kemampuan pesantren mempertahankan diri sebagai lembaga pendidikan yang tetap diminati masyarakat.

Pembicaraan tentang pesantren, tidak bisa dipisahkan dengan pembicaraan tentang kajian kitab kuning karena menjadi salah satu unsurnya di samping kiai, santri, asrama atau pondok, dan masjid atau musala. Kajian kitab kuning dijadikan prasyarat pengakuan keulamaan seseorang oleh masyarakat. Tingkat keulamaan seseorang ditentukan oleh kemampuannya dalam menjelaskan setiap kalimat dari kitab yang dikaji. ${ }^{1}$ Kemampuan dan penguasaan kitab kuning oleh kiai suatu pesantren, menentukan popularitas pesantren itu. Karena itu, kajian kitab kuning menjadi bagian yang tak terpisahkan dalam sistem kurikulum suatu pesantren. Menurut Ahmad Baso, tradisi kajian kitab sudah berlangsung sejak berabad-abad yang lalu dan tradisi peradaban Islam di Nusantara adalah tradisi peradaban kitab. Ini dibuktikan dengan adanya koleksi naskah kitab ulama-ulama di berbagai daerah, seperti di Banten dan berbagai pelosok Pulau Jawa dan pulau-pulau lain di Nusantara. ${ }^{2}$

Dalam perjalanan waktu, kurikulum di pesantren tidak hanya mengacu pada kajian kitab kuning. Kajian kitab kuning menjadi tereduksi, pesantren mengalami transformasi dalam berbagai bentuk, bahkan banyak pesantren yang sudah tidak mengajarkan kitab kuning lagi. Pemerintah melalui PMA nomor 13 Tahun 2014 mentolerir hal ini sebagaimana terlihat pada pasal 5 menyebutkan bahwa pesantren wajib memiliki pengajian kitab kuning atau dirāsah islāmiyyah dengan pola mu'al$\operatorname{limin.~}^{3}$

${ }^{1}$ Jajat Burhanuddin, Ulama dan Kekuasaan: Pergumulan Elite Muslim Dalam Sejarah Indonesia, (Jakarta: Mizan, 2012), hlm. 358-359

${ }^{2}$ Ahmad Baso, Pesantren Studies 2a. (Jakarta: Pustaka Afid, 2012), hlm. 135-140

${ }^{3}$ Peraturan Menteri Agama Nomor 13 Tahun 2014 Tentang Pendidikan Keagamaan Islam. 
Bertitik tolak pada latar belakang yang telah dikemukakan, dirumuskan masalah penelitian ini, yaitu: Bagaimana pembelajaran kitab kuning pada Pondok Pesantren Pesantren Ternate? Masalah penelitian ini secara lebih detail meliputi beberapa bagian untuk membatasi kajian penelitian ini, yakni: apa jenis kitab kuning yang diajarkan di Pondok Pesantren Hiyatullah Ternate, bagaimana mekanisme pemanfaatan kitab kuning di Pondok Pesantren Hidayatullah Ternate, serta bagaimana problem dan solusinya pemanfaatan kitab kuning di pondok pesantren.

Penelitian ini merupakan penelitian deskreptif kualitatif. Metode pengumpulan data yang digunakan yaitu wawancara, ${ }^{4}$ berpasangan dengan teknik observasi/pengama$\tan$ serta dokumentasi. Untuk memperkuat, teknik pengumpulan data tersebut, dilakukan studi kepustakaan atau referensi yang berkaiatan dengan kajian ini.

\section{PESANTREAN DAN KITAB KUNING}

Nasaruddin Umar membagi pesantren berdasarkan tipe pendidikannya ke dalam empat tipe, yaitu: (1) Pesantren yang menyelenggarakan pendidikan formal dengan menerapkan kurikulum nasional; (2) Pesantren yang menerapkan kurikulum keagamaan dan ilmu umum namun tidak mengikuti kurikulum nasional; (3) Pesantren yang hanya mengajarkan ilmu agama; serta (4) Pesantren yang hanya sekedar menjadi tempat pengajian. ${ }^{5}$

Amin Haedar mengemukakan bahwa terdapat tipologi pesantren yang mirip seperti yang disampaikan Nasaruddin Umar tersebut, sebagaimaan dikutip oleh Mardiyah. Yang membedakan hanya pada tipe ketiga yaitu pesantren yang mendirikan Madrasah Diniyah. ${ }^{6}$

\footnotetext{
4 John W. Cresswell. Research Design, Qualitative and Quantitative Approaches. (California: Thousand Oaks, 1994)

${ }^{5}$ Nasaruddin Umar, Rethinking Pesantren. (Jakarta: Elex Media Komputindo, 2014), hlm. 27-28

${ }^{6}$ Mardiyah, Kepemimpinan Kiai dalam Memelihara Budaya Organisasi. Cet. II, (Yogyakarta: Aditya Media Publishing, 2013), hlm. 466
} 
Martin Van Bruinessen mengemukakan bahwa pesantren merupakan pendidikan Islam tradisional khas Nusantara yang dalam prakteknya terpengaruh faktor dari luar khusunya dari Mekkah. Salah satu pengaruh itu adalah kajian kitab kuning yang disebut juga sebagai (kutub mu'tabarah). Banyak kitab kuning yang berbahasa Arab diajarkan di Indonesia bukan ditulis oleh penulisnya di Indonesia tetapi di Mekah walaupun ia adalah ulama Indonesia seperi Syaikh Nawawi al-Bantani. ${ }^{7}$

Pada tahun 1994, Balai Penelitian Lektur Keagamaan Ujung Pandang menerbitkan hasil penelitiannya berjudul transformasi kelekturan pesantren di Sulawesi Selatan. Kajian ini menyorot lima pesantren, yaitu: Pesantren As'adiyah Sengkang, Pesantren Manahil Ulum Kaballangan Pinrang, Pesantren Al-Urwatul Wustqa Sidrap, Pesantren Babul Khaer Bulukumba dan Pesantren Darul Istiqamah Maros. Kelima pesantren tersebut merupakan pesantren yang mengkombinasikan antara kurikulum khas kepesantrenan berupa kitab kuning dengan kurikulum Departemen Agama dan Departemen Pendidikan. Kajian ini menyebutkan beberapa kitab kuning yang dikaji di pesantren. ${ }^{\mathbf{2}}$

Perhatian Balai Litbang Agama Makassar terhadap kajian pesantren tinggi terlihat bahwa pada tahun 2011 dengan diadakannya penelitian Implementasi Pengajian Kitab pada Pondok Pesantren di Kawasan Timur Indonesia. Sebagian dari hasil penelitian tersebut telah diterbitkan dalam buku yang berjudul Reinversi Kurikulum dan Pembelajaran Pendidikan Agama dan Keagamaan. ${ }^{9}$

Kitab kuning adalah sebutan bagi kitab yang dijadikan referensi atau sumber belajar di pesantren dan berbagai lembaga pendidikan Islam tradisional di Nusantara. Ia sebenarnya merupakan karya tulis berbahsa Arab yang disusun oleh para ilmuwan muslim pada abad pertengahan sejarah Islam atau sekitar abad ke-16 sampai dengan

\footnotetext{
7 Martin Van Bruinessen, Kitab Kuning, Pesantren dan Tarekat. Cet. II, (Yogyakarta: Gading Publishing, 2015), hlm. 90

${ }^{8}$ Muhammad As'ad, "Transformasi Kelekturan pada Pesantren Manahil Ulum Kaballangan", dalam Transformasi Kelekturan Pesantren di Sulawesi Selatan, (Ujung Pandang: Balai Penelitian Lektur Keagamaan Ujung Pandang, 1994), hlm. 76-77

${ }^{9}$ Mujizatullah, "Implementasi Pengajian Kitab pada Pondok Pesantren Mambaush Shalichin AlHaramain", dalam Reinversi Kurikulum dan Pembelajaran Pendidikan Agama dan Pendidikan Keagamaan. (Jakarta: Orbit, 2011), hlm. 171-256
} 
abad ke-18 Masehi. Penyebutan kitab kuning siperkirakan karena kertas yang digunakan untuk menulis atau mencetak karya-karya tersebut berwarna kuning. ${ }^{10}$ Defenisi yang lebih luas tentang kitab kuning disebutkan dalam KMA nomor 13 tahun 2014 pasal 1 (3) yang berbunyi: "Kitab Kuning adalah kitab keislaman yang berbahasa Arab yang menjadi rujukan tradisi keilmuan di Pesantren." Pada realitasnya, kitab-kitab seperti itu diajarkan juga pada pengajian halaqah di masjid tertentu.

\section{KOTA TERNATE SEBAGAI LOKASI PENELITIAN}

Kota Ternate merupakan wilayah kepulauan yang meliputi 8 buah pulau. Tiga di antara pulau-pulau tersebut merupakan pulau kecil yang luasnya sekitar $0,5 \mathrm{~km}^{2}$ dan tidak berpenghuni, dan hanya 5 pulau yang berpenghuni, yaitu: Pulau Ternate, Pulau Hiri, Pulau Moti, Pulau Mayau, dan Pulau Tifuri. Kota Ternate dibagi menjadi 8 kecamatan dan dihuni oleh penduduk berjumlah 218.028 jiwa pada tahun 2016, terdiri atas laki-laki sebanyak 110.725 orang $(50,78 \%)$ dan perempuan sebanyak 107.303 orang $(49,22 \%) .{ }^{11}$

Mayoritas penduduk Kota Ternate tersebut menganut agama Islam, yaitu 215.267 orang atau mencapai 96,49\%. Penduduk yang menganut agama Kristen hanya 6.749 orang (3.02\%), dan selebihnya sebanyak 1.091 orang (0,49\%) menganut agamaagama Katholik, Hindu Budha dan Konghucu.

Tabel 1:

Komposisi Penduduk Kota Ternate Berdasarkan Pemelukan Agama pada Setiap Kecamatan Tahun 2016

\begin{tabular}{lccccccc} 
Kecamatan & Islam & Kristen & Katholik & Hindu & Budha & Konghucu & Jumlah \\
P. Ternate & 15.200 & 172 & 2 & 0 & 0 & 0 & 15.374 \\
\hline Moti & 5.097 & 0 & 0 & 0 & 0 & 0 & 5.097 \\
\hline
\end{tabular}

10 Martin Van Bruinessen, Kitab Kuning, Pesantren dan Tarekat: Tradisi-Tradisi Islam di Indonesia, Cet. I, (Bandung: Mizan, 1994), hlm. 42 


\begin{tabular}{lccccccc}
\hline P. Batang Dua & 6 & 2.890 & 3 & 0 & 0 & 0 & 2.899 \\
\hline P. Hiri & 2.908 & 0 & 0 & 0 & 0 & 0 & 2.908 \\
\hline Ternate Selatan & 79.815 & 880 & 71 & 16 & 28 & 8 & 80.818 \\
\hline Ternate Tengah & 60.669 & 2.336 & 598 & 138 & 28 & 145 & 63.914 \\
\hline Ternate Utara & 51.572 & 471 & 39 & 1 & 14 & 0 & 52.09 \\
\hline Kota Ternate & 215.267 & 6.749 & 713 & 155 & 70 & 153 & 223.107 \\
\hline
\end{tabular}

Sumber: (BPS Ternate, 2017)

Pada tabel di atas jelas terlihat bahwa kecuali Kecamatan Pulau Batang Dua mayoritas penduduknya beragama Islam, bahkan pada kecamatan Moti dan Kecamatan Pulau Hiri semua penduduknya beragama Islam. Sedang pada Kecamatan Pulau Batang Dua hampir semuanya beragama Kristen. Dari penduduk berjumlah 2.899 orang, yang beragama Islam hanya 6 orang dan yang beragama Katholik hanya 3 orang.

Rumah ibadah bagi umat Islam, berupa masjid 197 buah tersebar pada semua kecamatan yang ada kecuali pada Kecamatan Pulau Batang Dua karena rumah ibadah di kecamatan ini hanya bagi umat Kristen (gereja) berjumlah 10 buah dari 18 gereja bagi umat Kristen di Kota Ternate

Jumlah Madrasah di Kota Ternate, Tahun 2017/2018, Madrasah Ibtidaiyah 13 buah, Madrasah Tsanawiyah 11 buah, dan Madrasah Aliyah 6 buah. Beberapa madrasah swasta ada yang bernaung di bawah yayasan pondok pesantren. Pondok pesantren yang tercatat pada Kantor Kemenag Kota Ternate hanya tiga lembaga, yaitu: Pondok Pesantren Al-Khairaat, Pondok Pesantren Moluku Kie Raha, dan Pondok Pesantren Hidayatullah Ternate. ${ }^{12}$

12 Abd. Kadir Ahmad, "Pesantren Hidayatullah Gunung Tembak dan Issu Terorisme", dalam AlQalam Jurnal Penelitian Agama dan Sosial Budaya. No.XIX Tahun XIII, Edisi Januari - Juni 2007. (Makassar: Balai Penelitian dan Pengembangan Agama Makassar. 2007), hlm. 5 


\section{PONDOK PESANTREN DI KOTA TERNATE}

Sebagaimana telah disebutkan di muka bahwa pondok pesantren yang tercatat pada Kantor Kemenag Kota Ternate hanya 3 buah, yaitu: (1) Pondok Pesantren AlKhairaat Kalumpang Ternate; (2) Pondok Pesantren Hidayatullah Ternate; dan (3) Pondok Pesantren Moluku Kie Raha Ternate. Tetapi, selain itu, diketemukan dua pesantren lainnya yang belum tercatat di data Kemenag Kota Ternate, yaitu: (1) Pondok Pesantren Ulumuddin Ternate dan (2) Pondok Pesantren Darut Tahsin Ternate.

Pondok Pesantren Al-Khairaat Kalumpang Ternate yang berdiri sejak tahun 1964 M/1374 H bernaung di bawah Yayasan Al-Khairaat Cabang Kota Ternate. Pondok pesantren ini beralamat di Jl. Kakatua No. 155 Kelurahan Kalumpang, Kecamatan Ternate Tengah. Sebagai lembaga pendidikan, Pondok Pesantren Al-Khairaat Ternate membina satuan pendidikan berupa sekolah dan madrasah dari tingkat sekolah dasar sampai tingkat menengah atas. Pendidikan formal yang diasuh oleh pondok pesantren ini adalah: (1) SD 01 Al-Khairaat; (2) SD 04 Al-Khairaat; (3) SMP BP AlKhairaat; (4) MTs Al-Khairaat; (5) SMA Al-Khairaat; dan (6) MA Al-Khairaat.

Pondok Pesantren Al-Khairaat, pada tahun pelajaran 2017-2018, menampung siswa pada semua jenjang dan jenis satuan pendidikan tersebut sebanyak 1.206 orang, terdiri atas laki-laki sebanyak 683 orang dan perempuan sebanyak 523 orang. Siswa tersebut diasuh oleh tenaga pendidik sebanyak 108 orang, yang rinciannya adalah: guru tetap PNS sebanyak 82 orang, guru tetap yayasan 3 orang, dan guru tidak tetap sebanyak 23 orang. Hal ini menunjukkan bahwa bantuan pemerintah terhadap lembaga pendidikan berbasis pondok pesantren ini yang berupa tenaga pendidik sangat besar.

Sebagai pondok pesantren, tentu ada santri yang mondok di dalamnya. Hanya saja, kenyataannya, saat ini santri yang mondok sangat sedikit jumlahnya dibanding jumlah siswa yang seharusnya mondok. Tercatat hanya ada 20 orang santri putra. 
Santri yang mondok ini mempergunakan waktu sesudah salat magrib untuk pembelajaran. Namun, hampir tidah ada pengajian kitab kecuali kitab hadis, yaitu kitab Hadits Arba'īn.

Sementara itu, Pondok Pesantren Hidayatullah Ternate adalah salah satu dari sekian banyaknya pondok pesantren Hidayatullah yang tersebar di berbagai daerah di Indonesia. Sejumlah Pondok Pesantren Hidayatullah yang berpusat di Balikpapan Kalimantan Timur ini tersebar secara meluas di banyak tempat di Nusantara terutama, di Kawasan Timur Indonesia. Perkembangan ini mengiringi Pondok Pesantren Hidayatullah yang didirikan ormas Islam Hidayatullah yang memiliki cakupan nasional dan berpusat di Jakarta. Ormas yang memiliki misi utama di bidang pendidikan dan dakwah ini sangat berkomitmen dalam membangun lembaga pendidikan Islam, terutama pondok pesantren, sehingga pondok-pondok pesantren binaan $\mathrm{Hi}$ dayatullah tersebar di berbagai polosok Nusantara Indonesia.

Hidayatullah, sebagai organisasi sosial keagamaan, struktur organisasinya tertata dengan baik dari pusat ke daerah. Untuk tingkat pusat, terdapat Dewan Pimpinan Pusat yang berpusat di Jakarta; untuk tingkat propinsi ada Dewan Pimpinan Wilayah (DPW); dan untuk tingkat kabupaten kota ada Dewan Pimpinan Daerah (DPD).

Kepemimpinan Hidayatullah dibangun di atas manhaj nubuwwah yang melangkah mengikuti skala prioritas, mulai dari yang paling asasi (ush $\bar{u} l$ ) hingga yang merupakan cabang ( $f u r \bar{u})$. Sedangkan agenda utama yang menjadi fokus program Pesantren Hidayatullah adalah imämah dan jamä'ah (tajdìd); pencerahan kesadaran; pembersihan jiwa (tazkiyah al-nufüs); pengajaran dan pendidikan ( hikmah); menuju kepemimpinan dan umat yang moderat (wasath) dan terbaik. ${ }^{\mathbf{1 3}}$

Adapun Pondok Pesantren Moluku Kie Raha beralamat di Koloncucu Puncak, Kelurahan Toboleu, Kecamatan Ternate Utara. Pondok Pesantren yang berdiri sejak tahun 2010 ini bernaung di bawah Yayasan Al-Mulk Kie Raha. Satuan pendidikan yang dibina di dalam Pondok Pesantren ini adalah madrasah tsanawiyah, yaitu MTs 
Ulumul Quar'an. Siswa yang dibina pada madrasah tsanawiyah ini sebanyak 24 orang, laki-laki 21 orang dan perempuan 3 orang. Siswa tersebut terkelompok pada tiga kelas, yaitu: kls VII 8 orang, kls VIII 10 orang, dan kelas IX 6 orang. Madrasah ini dibina oleh tenaga pendidik sebanyak 19 orang. Sebagai bagian dari pondok pesantren, sebagian besar siswa madrasah Tsanawiyah tergolong santri mondok, yaitu sebanyak 13 orang dari siswa sebanyak 24 orang tersebut. Santri yang mondok sebanyak 18 orang termasuk 13 orang tersebut ditambah 2 orang dari madrasah Ibtidaiyah dan 3 orang siswa SMA yang belajar di luar kampus. Pembacaan kitab di pesantren ini dilakukan secara terbatas.

Di samping madarasah tsanawiyah, pesantren ini juga membina satuan pendidikan tingkat dasar, yaitu Madrasah Ibtidaiyah Ulumul Qur'an Wahdah Islamiyah. Dicantumkannya nama Wahdah Islamiyah pada madrasah ini memberi petunjuk bahwa pesantren ini dibina oleh organisasi Wahdah Islamiyah yang berpusat di Makassar. Madrasah ini masih berumur muda, baru berjalan 3 tahun. Pada tahun pelajaran 2017-2018, membina murid sebanyak 27 orang yang terkelompok pada 3 kelas, yaitu kelas I 6 orang, kelas II 9 orang, dan kelas III 12 orang. Madrasah ini dibina oleh tenaga pendidik sebanyak 9 orang, termasuk kepala madrasah.

Sementara itu, Pondok Pesantren Ulumuddin merupakan pesantren tahfiz Alquran yang bernaung di bawah Yayasan Ulumuddin Maluku Utara dan beralamat di Komplek Perumahan Fola Raha Bukit Kelurahan Kalumata Kecamatan Ternate Selatan. Pondok Pesantren Ulumuddin yang saat ini dipimpin oleh seorang kiai yang masih muda (34 tahun) berdiri sejak tahun 2009 dan pada tahun 2018 membina santri sebanyak 38 yang bervariasi umurnya antara 13 hingga 17 tahun. Santri pada pondok pesantren ini betul-betul fokus pada pengajian pesantren, tidak ikut dalam pendidikan formal di luar pesantren. Selain tahfiz, santri juga mengikuti pengajian kitab dari kiainya berkaitan dengan cabang-cabang ilmu fikih, hadis, dan sirah (sejarah Nabi dan sahabat). Kitab fikih yang diajarkan dari Imam Mazhab Empat. Sedang kitab hadis adalah Bukhari Muslim. Adapun kitab sìrah yang diajarkan adalah Syair- 
rahman. Untuk mendapatkan syahadah (bukti kelulusan atau ijazah), evaluasi kemampuan sangat ketat, sehingga baru satu orang yang dinyatakan berhasil, yaitu Hafiz Abd. Salam.

Kampus atau gedung pondok pesantren yang ditempati saat ini pada alamat tersebut hanya berupa rumah berlantai dua yang tidak terlalu besar. Lantai duanya berfungsi sebagai musalla, tempat belajar, dan tempat tidur santri. Untuk pengembangannya, pesantren ini sudah memiliki lahan sekitar 2 ha yang beralamat di Pitu Kecamatan Ternate Selatan.

Pesantren yang selanjutnya adalah Pondok Pesantren Darut Tahsin yang bernaung di bawah Yayasan Darut Tahsin Ternate. Pesantren ini adalah pondok pesantren di Kota ternate yang sangat muda usianya, yakni dimulai pada awal-awal tahun 2018. Yayasan ini merupakan sebuah yayasan keluarga, tidak bernaung di bawah suatu organisasi. Donatur utama yayasan ini adalah H. Muhammad Dg. Barang dan H. Ibrahim. Keduanya termasuk pengusaha sukses di Ternate. Kepemimpin yayasan ini dipercayakan kepada Hj. Sahibah Dg. Barang, saudara H. Muhammad Dg Barang.

Melihat namanya dapat dipahami bahwa pesantren ini fokus pada bacaan Alquran yang benar, di samping tahfiz Alquran. Santri diajar membaca Alquran dengan lancar, benar dan baik. Mengkaji Alquran dari segi qiraahnya, dan juga menghafal Alquran. Durasi belajar santri direncanakan selama 3 tahun, setiap semester santri dibebankan menghafal 5 juz, sehingga selesai 3 tahun sudah hafal 30 juz.

Ada tiga kegiatan pembelajaran Alquran yang diprogramkan dalam pondok pesantren ini, yaitu TPQ/TKQ, pesantren Alquran, dan MTB (Metode Tartil Bersajak). Santri yang ikut pada pesantren semuanya bermukim di pondok pesantren dan berada pada usia SD dan SMP. Jumlah santri mondok ini sebanyak 42 orang, laki-laki 21 orang dan perempuan 21 orang. Adapun yang ikut pada program Tahsin dengan MTB, semacam santri kalong, tergolong anak muda. Mereka biasanya belajar pada malam hari. Sementara ini ada 2 kelompok santri kalong ini, yaitu: (1) mahasiswa IAIN Ternate 6 orang; (2) Santri Tahfiz Gambessi Pondok Pesantren ini bernaung di bawah Yayasan Darut Tahsin Ternate. 
Kiai pengasuh Pondok Pesantren Darut Tahsin ini adalah seorang ahli qira`ah dan hafiz berasal dari Lombok Nusa Tenggara Barat, bernama Ihsanuddin Al-Lambaqiy yang berusia 35 tahun dan merupakan alumni dari PTIQ Jakarta tahun 2009. Sebelum belajar di PTIQ, ia telah menimba ilmu di Pondok Pesantren Uswatun Hasanah di Lombok sampai tahun 2001. Selanjutnya, ia belajar kitab kuning pada pondok pesantren Hidayatullah di Kediri sampai 2004. Kepakarannya dari segi qira'ah mendapat pengakuan dengan bersanad ke 37.

Kiai pesantren, Ihsanuddin Al-Lambaqiy, sengaja didatangkan oleh pengurus yayasan untuk memimpin pesantren tersebut. Pesantren ini baru dibuka pada Januari 2018. Santri yang diterima, laki-laki maupun perempuan, dipondokkan pada pondok yang berbeda dalam kampusnya yang merupakan bahagian dari gedung milik yayasan. Pesantren ini dibina 4 orang, yaitu kiainya sendiri dan dibantu oleh 3 orang. Tiga orang tersebut termasuk isterinya dan 2 orang lainya, 1 orang laki-laki dan 1 orang perempuan.

\section{PROFIL PONDOK PESANTREN HIDAYATULLAH TERNATE}

Pondok Pesantren Hidayatullah Ternate bernaung di bawah Yayasan Pondok Pesantren Hidayatullah Ternate. Yayasan ini berada di bawah binaan Dewan Pengurus Daerah (DPD) Hidayatullah Kota Ternate. Pondok Pesantren Hidayatullah Ternate membina santri putra dan santri putri yang keduanya berada pada kampus yang berbeda dengan jarak sekitar $1 \mathrm{~km}$. Kampus putra berada di Jl. Tengah Kalimata dan kampus putri terletak di Kalimata Puncak. Kedua kampus ini berada dalam wilayah Kecamatan Ternate Selatan.

Areal kampus I, putra berada di tengah-tengah pemukiman penduduk. Aral ini relatif sempit dengan topografi berbukit. Peletakan bangunan disesuaikan dengan topografi tersebut sehingga kelihatan bertingkat-tingkat. Areal paling atas sebelah timur terletak gedung SMP yang bertingkat dua, terdiri dari 8 lokal. Di sebelah selatannya terdapat gedung-gedung masjid lama (masjid Al-Taqwa), masjid baru 
(masjid Al-Hasan), gedung yang ditempati RA, dan gedung yang ditempati kantor yayasan. Gedung-gedung ini merupakan konstruksi permanen bertingkat dua. Bagian selatan areal, berderetan dengan gedung kantor, terdapat bangunan baru yang direncanakan bertingkat dan baru selesai tingkat dasar yang difungsikan sebagai asrama. Gedung lama, masjid Al-Taqwa tidak difungsikan kecuali sebagian lantai dasarnya sebagi rumah pembina. Kampus ini dibelah oleh jalan kampus bermula dari pintu gerbang di jalan tengah Kalumata. Sebelah selatannya mendaki sampai depan gedung SMP dan membelok ke timur masuk pemukiman penduduk. Di sebelah barat jalan kampus terletak lapangan upacara atau olah raga. Jalan kampus ini selalu terbuka untuk dilewati penduduk di sebelah timur kampus karena sebelumnya merupakan jalanan umum yang biasa digunakan penduduk setempat.

Areal kampus II, yakni putri berada pada lereng Gunung Gamalama sehingga disebut Kalumata Puncak. Luas areal ini sekitar 4050 m2, memanjang dari timur ke barat dan di depannya terdapat jalan raya. Di seberang jalan depan kampus terdapat 5 unit rumah untuk pengasuh pesantren. Semua gedung berlantai satu kecuali satu gedung yang panjangnya hanya dua local berlantai dua. Gedung ini berfungsi sebagai asrama bersama gedung lainnya yang sejejer dengannya. Gedung-gedung pada bagian timur kampus berfungsi sebagai ruang belajar dan kantor madrasah/sekolah. Bagian tengah sebagai asrama dan bagian barat sebagai rumah pengasuh. Musalla terdapat pada bagian barat kampus dekat rumah pengasuh.

Pondok Pesantren Hidayatullah Ternate sebagai lembaga pendidikan atau pondok pesantren didirikan pada tahun 1994. Secara historis, cikal bakal pondok pesantren ini adalah Panti Asuhan Al-Taqwa dan selanjutnya berubah nama menjadi Panti Asuhan Al-Huda. Anak-anak panti asuhan inilah yang menjadi santri Pondok Pesantren Hidayatullah Ternate. Para santri dididik secara kepesantrenan dalam kampus dan belajar pada sekolah formal di luar kampus. Pada tahun 2001, Pondok Pesantren Hidayatullah membuka sekolah dengan sistem Islamic Boarding School (sekolah Islam berasrama) pada jenjang pendidikan tingkat sekolah menengah pertama (SMP) yang diberi nama SMP Integral Ulul Albab. 
Pada tahun 1994-1995 sebagai perintis adalah Ustadz Syafruddin sekaligus pimpinan pertama, dilanjutkan oleh Ustadz Mardhatillah sebagai pimpinan kedua pada periode tahun1995-1996. Pimpinan ketiga adalah Ustadz Abd. Qadir Abdullah yang memegang tampuk pimpinan pada tahun 1996-2000. Pimpinan keempat, yakni pada tahun 2000-2005, adalah Ustadz Riadi Poniman. ${ }^{14}$ Selanjutnya secara estafet yayasan Hidayatullah dinakhodai masing-masing oleh Ustadz Ramadhani AK (periode tahun 2005-2007); Ustadz Muhammad Kamal (periode tahun 2007-20011); Ustadz Ahmad Yasman (periode tahun 2011-2016) dan Ustadz Ashar Abdul Gani (periode 2016 sampai dengan sekarang). ${ }^{15}$

Pondok Pesantren Hidayatullah Ternate membina satuan pendidikan berupa sekolah dan madrasah. Madrasah yang dibina oleh pondok pesamtren ini adalah tingkat ibtidaiyah dan aliyah, sedang sekolah yang dibina adalah pada tingkat menengah pertama. Selain itu, pondok pesantren ini juga mengelola pendidikan Anak Usia Dini (PAUD). Satuan pendidikan yang dikelola pada kampus putra adalah SMP BP dan TK Terpadu Ulul Albab. Sedang di kampus putri, satuan pendidikan yang dibina adalah madrasah ibtidaiyah dan madrasah aliyah. Selain itu, PP Hidayatullah juga membina Pusat Kegiatan Belajar Masyarakat (PKBM), yaitu program pendidikan yang berbasis ekonomi.

Siawa yang dibina oleh Pondok Pesantren Hidayatullah dalam keempat satuan pendidikan tersebut sebanyak 379 orang, yang rinciannya terlihat pada tabel berikut:

Tabel 2:

Siswa Madrasah/Sekolah Binaan Pondok Pesantren Hidayatullah

\begin{tabular}{llccc}
\multicolumn{2}{c}{ Sekolah/Madrasah } & Rombel & Siswa & Guru \\
1. & RA & 2 & 34 & 5 \\
\hline 2. & MI & 6 & 167 & 15 \\
\hline 3. & SMP & 6 & 122 & 20 \\
\hline
\end{tabular}

${ }^{14}$ Arifuddin Ismail, "Pesantren dan Radikalisme: Studi Kasus Pesantren Hidayatullah Ternate", dalam Al-Qalam Jurnal Penelitian Agama dan Sosial Budaya. No.XIX Tahun XIII, Edisi Januari - Juni 2007, (Makassar: Balai Penelitian dan Pengembangan Agama Makassar, 2007), hlm. 23-24

${ }^{15}$ Hasil wawancara dengan Ustadz Ashar Abdul Gani, tanggal 7 Februari 2018 di Kampus I Pondok Pesantren Hidayatullah Ternate 


\begin{tabular}{|c|c|c|c|}
\hline 4. MA & 3 & 56 & 13 \\
\hline Jumlah & 11 & 379 & 53 \\
\hline
\end{tabular}

\section{PEMBELAJARAN KITAB KUNING DI PONDOK PESANTREN HIDAYATULLAH TERNATE}

Pada pembicaraan tentang profil Pondok Pesantren Hidayatullah Ternate yang telah dikemukakan, terlihat santri putra dan santri putri masing-masing ditempatkan pada kampus yang berbeda. Oleh karena kedua kampus ini berada dalam suatu manajemen, pengelolaannya dalam 1 x 24 jam pada dasarnya sama. Kehidupan santri dalam kampus diatur oleh tata tertib yang memuat kegiatan harian yang dilakoni para santri secara rutin. Pada kampus putra, jadwal kegiatan harian sebagai berikut:

Tabel 3:

Jadwal Kegiatan Harian Santri Putra Tahun Ajaran 2017 - 2018

\begin{tabular}{cl} 
WAKTU & \multicolumn{1}{c}{ KEGIATAN } \\
\hline $04.00-05.00$ & Salat malam \\
\hline $05.00-06.00$ & Salat subuh + Wirid \\
\hline $06.00-07.00$ & Mandi, Makan, Uniforming \\
\hline $07.00-08.30$ & Hafalan Alquran \\
\hline $08.30-12.30$ & Pelajaran Kelas \\
\hline $12.30-14.00$ & Salat Zuhur + hafalan Hadis, Makan Siang \\
\hline $14.00-16.00$ & Pelajaran Kelas \\
\hline $16.00-17.00$ & Salat asar + Wirid \\
\hline $17.00-18.00$ & Kebersihan, Olah raga, Istirahat \\
\hline $18.00-18.30$ & Persiapan Salat Magrib \\
\hline $18.30-20.30$ & Salat Magrib, Diniyah, Salat Isya + wirid \\
\hline $20.30-21.30$ & Makan Malam \\
\hline $21.30-22.00$ & Belajar Mandiri, mengerjakan PR \\
\hline $22.00-04.00$ & Istirahat Malam \\
\hline
\end{tabular}

Dalam jadwal kegiatan tersebut, terlihat pendidikan formal dilakukan dua kali sehari, yaitu 08.30-12.30 dan 14.00-16.00. Sebelum siswa masuk belajar di kelas dilakukan aktivitas hafalan Alquran dari 07.00-08.30. 
Kegiatan kepesantrenan dilakukan berupa pembiasaan atau latihan dan pengajaran. Pembiasaan dan latihan untuk mengerjakan salat, baik sunnah maupun wajib. Salat sunnah yang dibiasakan adalah salat tahajjud (salat lail atau salat malam) dan salat dluha. Salat Fardlu dilakukan secara berjamaah setiap waktu salat. Salat-salat sunah rawātib sering dianjurkan tetapi kurang penekanan, terutama salat sunat tahiyyat masjid hampir tidak ada santri yang melakukannya. Pembacaan wirid berpedoman pada susunan wirid yang disusun untuk kalangan Hidayatullah dilakukan 3 kali sehabis salat fardhu, yaitu seudah salat subuh, sesudah salat Asar dan sesudah salat Isya.

Pengajaran kepesantrenan (kegiatan diniyyah) dilakukan berupa 2 kegiatan, yaitu pertama: halaqah diniyyah, berupa kajian Alquran dan Fikih (sesudah salat Subuh) dan hafalan hadis (sesudah salat dhuhur) dan kedua ta'līm dìniyyah atau pengkajian kitab sesudah sahlat Magrib. Pengkajian kitab ini pada dasrnya bukan hanya diperuntukkan bagi santri yang meondok tetapi semua jamaah yang ikut salat berjamaah. Taklim ini dilakuakan lima kali seminggu, yaitu setiap malam kecuali malam Jum'at. Jadwal ta'lim dinniyyah ini terlihat berikut:

\section{Tabel 4:}

Jadwal Ta'lim Dìniyyah Pondok Pesantren Hidayatullah Ternate

\begin{tabular}{|c|c|c|c|}
\hline Waktu & Pelajaran & Nama Kitab & Ustaz / Muallim \\
\hline Malam Senin & Fikih & Taudlih al-A $\underline{h} k \bar{a} m$ & Ridwan A. Sune \\
\hline Malam Selasa & Ensiklopedi & Minhāj al-Muslim & Ahmad Chairullah \\
\hline Malam Rabu & Tafsir & Tafsìr al-Sa'dī & Hijir \\
\hline Malam Kamis & Bhs. Arab & Al-'Arabiyyah bain Yadaik & Ashar Abdul Gani \\
\hline Malam sabtu & Sirah & Al-Rahīiq al-Makhtūm & Imam Asyhari \\
\hline
\end{tabular}

Dalam jadwal tersebut terlihat nama-nama kelima kitab yang diajarkan berkaitan dengan mata pelajaran tertentu. Penentuan kitab ini ditetapkan oleh pihak pimpinan pusat Hidayatullah sehingga dapat dikatakan kelimanya merupakan pegangan Hidayatullah. Kelima kitab itu berkaitan dengan fikih, aqidah, tafsir, sìrah, dan Bahasa Arab. 
Kitab Taudlīh al-A $\underline{h} k \bar{a} m$ yang dijadikan pegangan Ustadz/Muallim hanya terjemahannya yang sudah terekam dalam laptop (tidak ada buku aslinya). Kitab Minhāj alMuslim yang memuat Ensiklopedi yang dimulai dengan aqidah, yang dipegang Muallim adalah terjemahannya dan naskah aslinya sebagai referensi. Demikian pula Tafsìr al-Sa'dī ada terjemahannya dan ada naskah asli tetapi hanya referensi. Judul asli dari kitab Tafsìr al-Sa'dī adalah Tafsìr al-Karìm al-Rahnmān fì Tafsìr al-Kalām al-Mannān. Pengarangnya adalah Syaikh 'Abd al-Rahmān ibn Nashīr al-Sa'dī. Kitab al-Rahīq al-Makhtūm yang menjadi pegangan Muallim hanya terjemahannya. Pengarang dari kitab ini adalah Syaikh Shafĩ al-Rahmmān al-Mubārakfūrī. Adapun kitab al-'Arabiyyah bain Yadaik, meskipun berbahasa Arab, tetapi tidak mendukung kemampuan berbahasa Arab untuk pembacaan kitab kuning. Kitab ini lebih tepat dipergunakan untuk mempelajari percakapan dalam Bahasa Arab atau latihan percakapan Bahasa Arab,

Kelima ustadz/muallim yang mempertanggung jawabkan pengkajian kelima kitab yang telah dikemukakan, ada merupakan kader binaan Hidayatullah. Ada juga beberapa muallim yang berasal dari luar Hidayatullah dan mengambil bahagian dalam Hidayatullah di Ternate. Ustadz Ashar Abdul Gani yang saat ini memegang jabatan sebagai Pimpinan Pondok Pesantren Hidayatullah Ternate, Pimpinan Yayasan Hidayatullah Ternate, dan Ketua DPD Hidayatullah Ternate, merupakan kader binaan Hidyatullah. Ia adalah putra kelahiran Bone yang pernah menjadi santri pada Pondok Pesantren Biru di Bone pada tingkat Tsanawiyah (1995-1998). Sebagai kader Hidayatullah ia mulai saat mondok di Pondok Pesantren Hidayatullah Bontang (1999 - 2002) dan mengikuti pendidikan formal pada SMA Hidayatullah. Selanjutnya melanjtkan kuliah pada Sekolah Tinggi Agama Islam Lukmanul Hakim (STAIL) dalam lingkungan Hidayatullah Surabaya dan menyelesaikan S1 pada tahun 2006. Pada tahun ini juga, ia ditugaskan mengabdi pada Pondok Pesantren Hidayatullah Ternate. Pengabdiannya pada Pondok Pesantren Hidayatullah Ternate cukup lama pada Madrasah Ibtidaiyah (MI) sebagai kepala madrasah tahun 2006-2016.

Ustadz Ridwan adalah kader Hidayatullah dari Gorontalo yang pernah momdok di Pondok Pesantren Hidayatullah Bitung, kemudian Pondok Pesantren Hidayatullah Gorontalo dan terakhir kuliah pada STAIL Hidayatullah Surabaya seperti Ustadz 
Anshar dan lulus pada tahun 2007. Kedatangannya di Ternate 2016 atas permintaan Ustadz Ansar.

Ustadz Khairullah adalah kader Hidayatullah dari Ternate yang mondok di Hidayatullah Ternate saat belajar di tingkat SMP. Kemudian melanjutkan pendidikannya pada Pondok Pesantren Hidayatullah Pusat di Balikpapan sampai lulus pada sekolah Menengah atas dan melanjutkan kuliahnya pada Al-Bi ir Makassar dan tamat pada program Diploma. Untuk memperbaiki qira'ahnya, ia mengikuti pengajian sebagai santri kalong pada Pondok Pesantren Darut Tahsin Ternate.

Dua muallim lainnya yang bukan kader langsung dari Hidayatullah adalah Ustadz Hijir dan Imam Asyhari. Ustadz Hijir adalah putra Ternate yang setamat SMP di Ternate melanjutkan pendidikan pada Pondok Pesantren al-Irsyad Bondowoso, yaitu pada MAK (Madrasah Aliyah Keagamaan). Pesantren ini tergolong pesantren modern. Kemudian ia melanjutkan pada LIPIA Jakarta selama 3 tahun. Tingkat sarjana ia selesaikan pada STAIN Ternate. Adapun Ustadz Imam Asyhari berlatar pendidikan pesantren yang mengajarkan kitab kuning. Pernah mengikuti pendidikan pesantren pada tiga pesantren, antara lain Pondok Pesantren Darussalam Tulung Agung, Banyuwangi dan Pondok Pesantren Baitul Makrifah, sebuah pondok pesantren salafiyah binaan NU. Karena merasa cukup pengajian kitab kuningnya dan faktor lainnya, seperti masalah ekonomi, pertimbangan usia yang telah mencapai 25 tahun, maka ia hanya menempuh satu tahun pada tingkat Ulya. Ia merantau ke Ternate pada tahun 2004 dengan bekerja pada sektor non formal.

\section{MEKANISME DAN PROBLEMATIKA DALAM PENGKAJIAN KITAB KUNING DI PONDOK PESANTREN HIDAYATULLAH TERNATE}

Pengajian kitab dilakukan antara salat Magrib dan salat Isya, yaitu setelah selesai melakukan salat Maghrib. Pengajian ini berbentuk halaqah di depan mihrab masjid. Ustaz duduk bersila di tengah menghadap kepada santri (ke timur). Di depannya pada santri juga duduk bersila membentuk setengah lingkaran bersaf-saf. Di depan 
Ustaz diletakkan kitab bahasan dan santri tidak ada yang memilikinya dan juga tidak menyediakan buku catatan. Ustaz membahas kitab rujukan dengan pengantar bahasa Indonesia. Metode yang dipergunakan adalah $\operatorname{sim} \bar{a} \bar{\imath}$ (ceramah). Keterlibatan santri dalam pembahasan kitab rujukan tidak ada. Mereka hanya menyimak paparan ustaz. Ustaz tidak membaca bahasa asli (bahasa Arab) dari materi bahasan dan menerjemahkannya apalagi menyuruh santri membacanya karena memang santri tidak memiliki kitab yang dikaji.

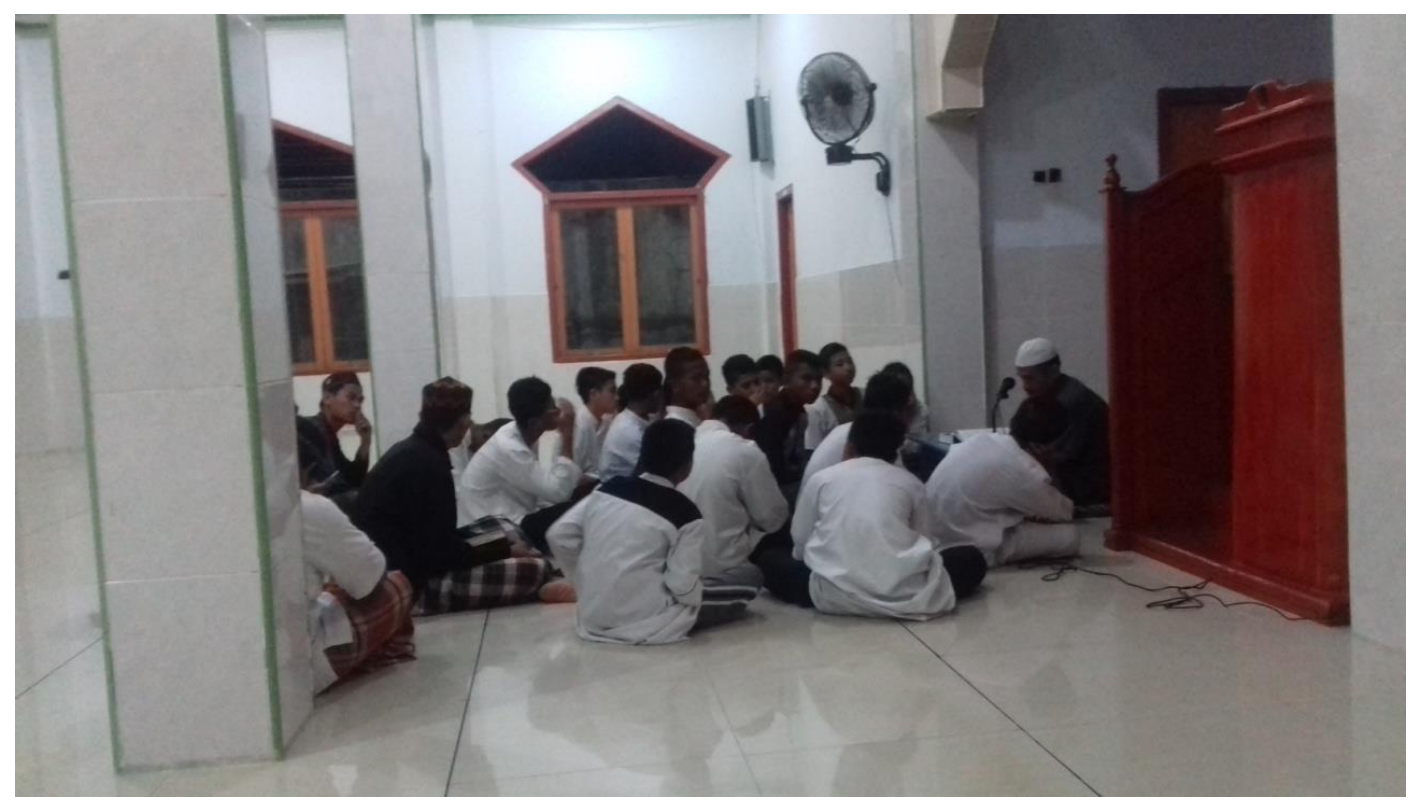

Gambar 1:

Pengajian kitab di masjid Al Hasan Kampus Putra PP Hidayatullah Ternate

Kitab kuning adalah kata lain dari kitab rujukan umat Islam berbahasa Arab. Karena kitab demikian ini tidak memakai tanda baca, maka biasa juga dinamai kitab gundul. Meskipun sudah banyak kitab kuning yang sudah diterjemahkan ke dalam bahasa Indonesia, sehingga membantu mengkaji isinya, tetapi diakui bahwa mengkaji kitab kuning melalui terjemahannya tidak sebaik mengkaji langsung sumber aslinya, karena terjemahan hanya satu versi dari kandungannya.

Mengkaji dan memahami isi kitab kuning tidak dapat dilakukan tanpa kemampuan yang memadai dalam penguasaan bahasa Arab. Bahkan, tidak semua orang yang mampu berbicara dengan Bahasa Arab, otomatis mampu mengkaji kitab kuning. 
Diakui bahwa kemampuan berbahasa Arab untuk mengkaji kitab kuning bagi muallim yang mengkaji kitab di lingkungan Pondok Pesantren Hidayatullah pada umumnya masih terbatas. Lebih-lebih santri yang mengikuti pengkajian ini.

Selain itu, pengadaan kitab tersebut merupakan kesulitan tersendiri sehingga kitab yang dikaji hanya dimiliki oleh muallim. Para santri tidak memilikinya. Bahkan buku aslinya tidak dimiliki semua muallim. Hal ini memiliki imbas yang sangat besar pada proses pengajian kitab-kitab tersebut. Santri tidak dapat berperan aktif dalam proses pengajian, dalam arti tidak dapat menyimak teks kitabnya dan membubuhi catatan-catatan yang dalam istilah tradisi pesantren disebut dengan istilah ngaji bandongan.

\section{KESIMPULAN}

Ta'līm Dìniyyah (pembelajaran kitab kuning) pada Pondok Pesantren Hidayatullah Ternate diaktifkan kembali pada tahun ajaran 2017/2018 bagi santri di kampus putra. Sedangkan di kampus putri baru diaktifkan pada tahun ajaran berikutnya. Pengajian kitab di kampus putri hanya untuk santri dari MA. Kitab yang dijadikan rujukan berkaitan dengan cabang ilmu agama ditentukan oleh Pengurus Pusat Pondok Pesantren Hidayatullah.

Ta'lim Dinniyyah yang dilakukan pada kedua kampus Pondok Pesantren Hidayatullah Ternate sama, baik kitab maupun nama pengajarnya (muallim). perbedaannya hanya hanya terletak pada waktu pelaksanannnya. Ta'lim ini dilakukan lima malam dalam seminggu, dan dilaksanakan antara salat Maghrib dan salat Isya. Lima orang muallim pengkajian kitab ini adalah para kader Hidayatullah sendiri ditambah ustadz yang direkrut di Ternate. Pegangan muallim dalam pengkajiannya adalah terjemahan kita kuning yang diajarkan, dan hanya ada dua muallim yang mengikutkan kitab aslinya sebagai rujukan. Teknik pengkajiannya adalah sistim ceramah, dalam arti muallim menjelaskan sedangkan santri mendengarkannya tanpa memiliki kitab pegangan masing-masing. Santri putra 
cenderung tidak membawa buku catatan, sedangkan santri putri membawa buku catatan, bahkan terjadi dialog, sehingga pengkajian lebih hidup.

Problem utama pemanfaatan teks asli kitab yang dikaji adalah kemampuan berbahasa yang dibutuhkan untuk pengkajian itu sangat minim bagi muallim dan bagi santri sendiri dapat dikatakan hampir tidak ada. Problem kedua adalah pengadaan kitab asli masih menjadi kesulitan.

Dari hasil penelitian tersebut di muka, peneliti memberikan saran atau rekomendasi bagi pihak-pihak terkait dengan subyek penelitian ini. Pertama, bagi pemerintah, bahwa Kementerian Agama perlu menyusun regulasi yang jelas tentang pembedaan antara pesantren yang mengajarkan kitab kuning, sebagai pencetak ulama dan pesantren lainnya. Pesantren pencetak ulama, karena sangat dibutuhkan, perlu mendapatkan perhatian dan pelayanan tersendiri yang bersifat khusus. Kedua, Pondok Pesantren Hidayatullah perlu membina pesantren khusus yang mengkaji kitab kuning dengan penguatan pembelajaran Bahasa Arab untuk itu. Para muallim untuk pengkajian kitab kuning juga perlu dibina khusus pada pesantren ini. Keluaran pesantren khusus ini yang akan menggalakkan pembelajaran kitab kuning pada pesantren-pesantren lainnya. [] 


\section{REFERENCES}

Ahmad, Abd. Kadir. (2007). "Pesantren Hidayatullah Gunung Tembak dan Issu Terorisme”, dalam Al-Qalam Jurnal Penelitian Agama dan Sosial Budaya. No.XIX Tahun XIII, Edisi Januaqri-Juni 2007. Makassar: Balai Penelitian dan Pengembangan Agama Makassar

As'ad, Muhammad. (1994). "Transformasi Kelekturan Pada Pesantren Manahil Ulum Kaballangan" dalam Transformasi Kelekturan Pesantren di Sulawesi Selatan. Ujung Pandang: Balai Penelitian Lektur Keagamaan Ujung Pandang.

BPS Kota Ternate. Kota Ternate Dalam Angka 2017

Baso, Ahmad. (2012). Pesantren Studies 2a. Jakarta: Pustaka Afid.

Van Bruinessen, Martin. (2009). Kitab Kuning, Pesantren dan Tarekat: TradisiTradisi Islam di Indonesia, Cet. I, Bandung: Mizan ,(2015) Kitab Kuning, Pesantren dan Tarekat. Cet. II; Yogyakarta: Gading Publishing.

Burhanuddin, jajat. (2012). Ulama dan Kekuasaan: Pergumulan Elite Muslim dalam Sejarah Indonesia, Jakarta: Mizan

Cresswell, Jhon W. (1994). Research Design, Qualitative and Quantitative Approaches, California: Thousand Oaks

Ismail, Arifuddin. (2007) "Pesantren dan Radikalisme: Studi Kasus Pesantren Hidayatullah Ternate, dalam Al-Qalam Jurnal Penelitian Agama dan Sosial Budaya. No.XIX Tahun XIII, Edisi Januaqri-Juni 2007. Makassar: Balai Penelitian dan Pengembangan Agama Makassar.

Mardiyah. (2013). Kepemimpinan Kiai dalam memelihara Budaya Organisasi. Cet. II; Yogyakarta: Aditya Media Publishing, 2013.

Mujizatullah. (2011). "Implementasi Pengajian Kitab pada Pondok Pesantren Mambaush Shalichin Al-Haramain", dalam Reinversi Kurikulum dan 
Pembelajaran Pendidikan Agama dan Pendidikan Keagamaan. Jakarta: Orbit.

Umar, Nasaruddin. (2014). Rethinking Pesantren. Jakarta: Elex Media Komputindo.

Peraturan Menteri Agama Nomor 13 Tahun 2014 Tentang Pendidikan Keagamaan Islam. 